\title{
Effects of milk replacer feeding rate and long-term antibiotic inclusion in milk replacer on performance and nutrient digestibility of Holstein dairy calves up to 4 months of age
}

\author{
T. S. Dennis, F. X. Suarez-Mena, ${ }^{*}$ W. Hu, T. M. Hill, J. D. Quigley, and R. L. Schlotterbeck \\ Nurture Research Center, Provimi, Cargill Animal Nutrition, Brookville, OH 45309
}

\section{ABSTRACT}

The objectives of this study were to evaluate calf performance and diet digestibility when feeding a milk replacer (MR; $25 \%$ crude protein, $18 \%$ fat, dry matter basis) at a moderate (MOD) and high (HI) rate, along with MOD with neomycin-oxytetracycline inclusion (1.43 each g/kg; NTMOD). Male Holstein calves ( $\mathrm{n}=48 ; 45 \pm 1.0 \mathrm{~kg}$ of body weight; 3 to $4 \mathrm{~d}$ of age) were housed in individual pens for $56 \mathrm{~d}$. All calves were initially fed $0.66 \mathrm{~kg}$ of dry matter from MR for the first p.m. and following a.m. feeding, then randomly assigned to 1 of 2 feeding programs: (1) $0.66 \mathrm{~kg}$ of dry matter/d for first $39 \mathrm{~d}$ divided into 2 equal a.m. and p.m. meals and $0.33 \mathrm{~kg}$ for $3 \mathrm{~d}$ fed once daily in the a.m. feeding only (MOD, NTMOD); (2) $0.85 \mathrm{~kg}$ of dry matter/d for the first $4 \mathrm{~d}$ divided into 2 equal a.m. and p.m. meals, $1.07 \mathrm{~kg}$ of dry matter/d for the next $31 \mathrm{~d}$ divided into 2 equal a.m. and p.m. meals, and $0.48 \mathrm{~kg}$ for $7 \mathrm{~d}$ fed once daily in the a.m. feeding only (HI). Calves were fed a textured starter containing whole grains $(20 \%$ crude protein, $43 \%$ starch, dry matter basis). Fecal samples were collected for 5 individual calves per treatment between d 47 to 51 to estimate digestibility. Calves were moved into groups by treatment (4 calves/pen) at 56 $\mathrm{d}$ and fed the same starter blended with $5 \%$ hay until d 112. Data were analyzed as a completely randomized design with repeated measures when applicable using mixed models. Milk replacer dry matter intake averaged $27.4 \mathrm{~kg}$ for MOD and NTMOD and $40.3 \mathrm{~kg}$ for HI per calf. Preweaning starter intake was less for calves fed HI versus MOD. Preweaning calf BCS change was greater for calves fed HI versus MOD. Preweaning medical treatment days were fewer for calves fed NTMOD versus MOD. Postweaning starter intake was less for calves fed HI versus MOD. Postweaning average daily gain was less for calves fed NTMOD versus

Received September 5, 2018

Accepted October 25, 2018.

*Corresponding author: xsuarez@provimi-na.com
MOD. Over the 56-d nursery trial, calves fed HI had less starter intake than calves fed MOD. Digestibility of dry matter, organic matter, acid detergent fiber, and neutral detergent fiber were greater for calves fed MOD versus NTMOD or HI during d 47 to 51 postweaning. Additionally, digestibility of fat was greater for calves fed MOD versus HI. During d 56 to 112, hip width change was greater for calves fed MOD versus NTMOD or HI. Over 0 to 112 d, body weight gain was 100, 98 , and $102 \mathrm{~kg}$, whereas hip width change was 10.2 , 9.0 , and $9.2 \mathrm{~cm}$ for calves fed MOD, NTMOD, and HI, respectively. Any preweaning improvements from feeding NTMOD or HI over MOD were lost during the postweaning period, which could be partially explained by reductions in diet digestibility.

Key words: calf, digestibility, antibiotics

\section{INTRODUCTION}

The dairy industry has continually moved toward feeding more milk or milk replacer (MR) to young calves for benefits in improved growth rates (Diaz et al., 2001), health outcomes (Ballou et al., 2015), welfare (von Keyserlingk et al., 2009), and potential for improved milk production in the first and subsequent lactations (Gelsinger et al., 2016). However, some studies have illustrated that dry feed intake is equally influential on increasing early growth rates and later performance in lactation in replacement heifers (Gelsinger et al., 2016; Chester-Jones et al., 2017). When more milk or MR is fed to a calf, starter intake is less. The substitution of starter intake for milk or MR is a relatively small amount of total DMI $(<15 \mathrm{~kg})$ over the first 4 mo of a calf's life. However, the delay in starter intake can slow rumen development and reduce starter digestibility pre- and postweaning (Terré et al., 2007a,b; Hill et al., 2010, 2016b). Reduced postweaning digestion can also last 4 wk or more (Hill et al., 2016b; Dennis et al., 2018). Growth advantages are frequently lost by 4 mo of age when comparing milk or MR programs that deliver a moderate amount of DM $(0.66 \mathrm{~kg}$ of $\mathrm{DM} / \mathrm{d}$ ) to programs that feed more than $0.66 \mathrm{~kg}$ of 
DM (Hill et al., 2007, 2016a,b). A few studies have suggested gradual weaning from high milk or MR feeding rates is needed to initiate earlier starter consumption and transition the calf to dry feed to avoid in slumps in growth during and after weaning (Eckert et al., 2015; Meale et al., 2015). However, several recent studies have not been able to identify successful milk feeding and weaning programs to ameliorate disruptions in digestibility and maintain growth rates after feeding high rates of milk or MR (Hill et al., 2016a,b; Dennis et al., 2018).

Increasing milk or MR feeding rates has been suggested to reduce morbidity and mortality in calves, possibly through enhanced immunity (Griebel et al., 1987; Ballou, 2012; Ballou et al., 2015). Griebel et al. (1987) found that feeding $50 \%$ below maintenance protein and energy requirements reduced immune function in calves under $4 \mathrm{wk}$ of age, whereas Ballou (2012) and Ballou et al. (2015) suggested that feeding high planes of nutrition improved immune function in Holstein and Jersey calves. Ollivett et al. (2012) reported quicker recovery from Cryptosporidium parvum infection and greater ADG if calves were fed a high plane of nutrition $(0.30$ Mcal of $\mathrm{ME} / \mathrm{kg}$ of $\mathrm{BW}^{0.75}$ using a $28 \%$ protein, $20 \%$ fat MR) compared with a low plane of nutrition $(0.13$ Mcal of ME $/ \mathrm{kg}$ of $\mathrm{BW}^{0.75}$ using a $20 \%$ protein, $20 \%$ fat MR). However, some studies have reported similar or greater morbidity rates from feeding more milk or MR (Quigley et al., 2006; Hengst et al., 2012; Bach et al., 2013a).

Morbidity and mortality rates are major concerns on calf-raising operations. A recent survey of 104 commercial operations in the United States ( $\mathrm{n}=2,545$ calves) reported $38 \%$ of calves had at least one morbidity event, with $56 \%$ of those calves diagnosed with enteric disease and $33 \%$ of calves displaying respiratory disease (Urie et al., 2018). On the operations surveyed, nearly $14 \%$ of all calves enrolled were given antibiotics in milk or MR (Urie et al., 2018). In a survey of farms in California, $56 \%$ of calves were fed a medicated MR and $54 \%$ of farms added a medication to prevent diarrhea and respiratory sickness (Walker et al., 2012). While antibiotic usage in calf feeds has declined over the last $25 \mathrm{yr}$, some farms continue to prophylactically administer antibiotics in liquid feeds to reduce morbidity. Additionally, many farms (62\% of operations surveyed in Urie et al., 2018) feed a combination of MR with waste milk or waste milk alone, which may contain low levels of antibiotic residues. One university study reported feeding neomycin sulfate and oxytetracycline in MR for 14, 26, or 42 d increased starter intake, improved feed efficiency, and reduced days with diarrhea compared with no antibiotic use (Litherland et al., 2010). However, Berge et al. (2009) reported in- cluding neomycin sulfate and tetracycline $\mathrm{HCl}$ in waste milk fed to calves without clinical signs of disease and with adequate passive transfer reduced starter intake, BW gain, and increased diarrhea on a large commercial farm. Several studies have illustrated continual feeding of antibiotics in waste milk can result in shedding of antimicrobial-resistant pathogenic bacteria (Berge et al., 2006; Maynou et al., 2017) and may also modify rumen bacterial populations in calves (Li et al., 2017).

As there are mixed responses to MR feeding rates and prophylactic treatment with antibiotics in the literature, one objective of this trial was to identify effects of moderate and high MR feeding rates on DMI, digestibility estimates, and health outcomes, including postweaning data to 4 mo of age. The second objective was to investigate the use of neomycin sulfate and oxytetracycline on health, performance, and digestibility estimates of calves pre- and postweaning. We hypothesized feeding more than $0.66 \mathrm{~kg}$ of $\mathrm{DM}$ from MR would improve early growth but reduce postweaning digestion and growth and feeding antibiotics in MR would improve calf performance.

\section{MATERIALS AND METHODS}

All animals were cared for as described in the Guide for the Care and Use of Agricultural Animals in Agricultural Research and Teaching (FASS, 2010). Male Holstein calves (48 head initially; 3 to $4 \mathrm{~d}$ of age) were received at the Nurture Research Center located in southwest Ohio from a commercial dairy farm after a $3.5 \mathrm{~h}$ transit. The calves were housed in individual pens $(1.2 \mathrm{~m} \times 2.4 \mathrm{~m})$ with a coarse rock, tile-drained base bedded with wheat straw in a barn with curtain sides, natural ventilation, and no added heat. The day after arrival at approximately noon, the calves were weighed (d $0 ; 45 \pm 1.4 \mathrm{~kg}$ of initial BW). At this time, blood was sampled intravenously, serum was separated by centrifugation at $3,000 \times g(\mathrm{VWR}$, Batavia, IL $)$ at $20^{\circ} \mathrm{C}$ for $15 \mathrm{~min}$, and serum protein concentration was estimated using an optical refractometer (ATAGO U.S.A., Inc., Bellevue, WA). Calves were fed 1 of 3 MR treatments: (1) MR (25\% CP, $18 \%$ fat, DM basis; Table 1) fed at a moderate rate (MOD); (2) MOD with addition of neomycin-oxytetracycline (1.43 g/ kg each; Phibro Animal Health Corp., Teaneck, NJ; NTMOD); or (3) MR fed at a high rate $(\mathbf{H I})$. All calves were initially fed $0.66 \mathrm{~kg}$ of DM from MR without medication for the first p.m feeding after arrival and the following a.m. feeding. Calves were then randomly assigned to 1 of 2 feeding programs: (1) $0.66 \mathrm{~kg}$ of $\mathrm{DM} / \mathrm{d}$ for first $39 \mathrm{~d}$ divided into 2 equal a.m. and p.m. meals and $0.33 \mathrm{~kg}$ for $3 \mathrm{~d}$ fed once daily in the a.m. feeding only (MOD and NTMOD); or (2) $0.85 \mathrm{~kg}$ of $\mathrm{DM} / \mathrm{d}$ for the first 4 
Table 1. Analyses of feeds used in the trials

\begin{tabular}{|c|c|c|c|c|}
\hline \multirow[b]{2}{*}{ Nutrient } & \multicolumn{2}{|c|}{ Nursery } & \multicolumn{2}{|c|}{ Grower } \\
\hline & Milk replacer & Starter & Starter & Hay \\
\hline DM & 96.3 & 87.8 & 87.5 & 87.1 \\
\hline $\mathrm{CP}$ & 24.8 & 20.5 & 20.3 & 10.2 \\
\hline $\mathrm{ADF}$ & - & 6.9 & 6.5 & 43.9 \\
\hline NDF & - & 14.5 & 13.7 & 64.6 \\
\hline Sugar & - & 6.4 & 5.9 & 10.6 \\
\hline Starch & - & 39.3 & 40.2 & 1.2 \\
\hline Fat & 18.3 & 3.83 & 3.75 & 1.6 \\
\hline Ash & 5.58 & 6.74 & 6.83 & 9.11 \\
\hline
\end{tabular}

d divided into 2 equal a.m. and p.m. meals, $1.07 \mathrm{~kg}$ of $\mathrm{DM} / \mathrm{d}$ for the next $31 \mathrm{~d}$ divided into 2 equal a.m. and p.m. meals, and $0.48 \mathrm{~kg}$ for $7 \mathrm{~d}$ fed once daily in the a.m. feeding only (HI). Milk replacer was reconstituted with warm water to $14 \%$ solids and fed twice daily at 0600 and $1530 \mathrm{~h}$. The MR used was formulated with added synthetic AA (Hill et al., 2008) and fatty acids (Hill et al., 2011). Rejected MR was weighed back after each feeding. A whole-grain, textured calf starter $(20 \%$ CP, 39\% starch with specific fatty acids added as in Hill et al., 2011; Table 1) and water were fed for ad libitum intake during the nursery trial. Every other bag of MR and calf starter was sampled and composited for nutrient analysis.

Calves were weighed weekly during the nursery trial. Hip widths were measured using a caliper and BCS were assessed by palpating the transverse process by one experienced technician ( 1 being thin to 5 being obese; modified from Wildman et al., 1982) on d 0, 14, 28,42 , and 56 . Feces were scored daily using a 1 to 5 scale with 1 being normal and 5 being watery (modified from Kertz and Chester-Jones, 2004). Antibiotic medical treatments were recorded daily and were based on the calf displaying lethargy, coughing, nasal discharges, or rectal temperatures $>39.4^{\circ} \mathrm{C}$. Calves with fecal scores $>2$ received oral electrolytes, but these were not counted as medical treatments.

Five calves/treatment were randomly selected for use to estimate diet digestibility postweaning (d 47 to 51). Fecal grab samples were palpated rectally and composited by calf for use to estimate total-tract diet digestibility as described by Hill et al. (2016a). Acidinsoluble ash was used as an internal marker. The nursery pens were bedded with long wheat straw, and straw consumption by calves was possible (Hill et al., 2010, $2016 a, b)$. This was accounted for by not adding new bedding $3 \mathrm{~d}$ before and during fecal collection periods to minimize the chance of straw intake during the week of digestibility measurements. Mathematically, unaccounted for consumption of straw could have reduced estimates of digestibility.
On d 56, calves from the nursery trial were grouped by preweaning treatment and moved to pens (4 calves/ pen within treatment) for the grower trial until $112 \mathrm{~d}$ of age. The pens had $6.5 \mathrm{~m}^{2}$ of outside pen space and 1.35 $\mathrm{m}^{2}$ of inside pen space bedded with wheat straw per calf. Calf starter used in the nursery trial was blended with $5 \%$ chopped grass hay (approximately $2.5 \mathrm{~cm}$ long) on an as-fed basis and fed for ad libitum intake with free-choice access to water. Grower feed refusals were weighed daily to determine DMI. Every other bag of starter and every bale of hay was sampled and composited for nutrient analysis. Calf BW, hip width, and BCS were determined on d 56, 84, and 112 .

Composites of feeds, refusals, and feces were analyzed (AOAC International, 2000) for DM (oven method 930.15), ash (oven method 942.05), CP (Kjeldahl method 988.05), fat (alkaline treatment with RoeseGottlieb method 932.06 for MR; diethyl ether extraction method 2003.05 for starters and hay), NDF with ash by the procedure of Van Soest et al. (1991) without sodium sulfite or $\alpha$-amylase, ADF with ash (Robertson and Van Soest, 1981), starch ( $\alpha$-amylase method; Hall, 2009), sugar (colormetric method; Dubois et al., 1956), and acid insoluble ash (Van Keulen and Young, 1977). The trials were conducted from January through May 2016. The average temperature in the nursery trial was $0^{\circ} \mathrm{C}$ with a range from -18 to $21^{\circ} \mathrm{C}$. The average relative humidity was $82 \%$ with a range from 28 to $100 \%$. The average temperature in the grower trial was $10^{\circ} \mathrm{C}$ with a range from -4 to $28^{\circ} \mathrm{C}$. The average relative humidity was $76 \%$ with a range from 20 to $100 \%$.

In the nursery trial, data of daily intakes were reduced to weekly means for each calf. In the grower trial, data of daily intake were reduced to means in 28-d periods for each pen of calves. All data were analyzed as a completely randomized design, or when applicable a completely randomized design with repeated measures in wk, or in 14-, or 28-d periods, respectively, using MIXED procedures (version 8, SAS Institute Inc., Cary, NC). Calf in the nursery trial and pen (4 calves/ pen) in the grower trial were the experimental units. 
In the mixed models with repeated measurements, calf or pen was treated as a random variable and the firstorder autoregressive structure type was selected as the appropriate covariance structure based on goodness-offit criteria (lowest Akaike information criterion; Littell et al., 1998). Significance was defined as $P \leq 0.05$, whereas $0.05<P \leq 0.10$ was considered to indicate a trend toward a significant effect.

\section{RESULTS}

\section{Feed Intake and Growth Performance}

Initial hip widths were less for calves fed MOD than calves fed NTMOD and HI and initial BW tended to be less for MOD compared with NTMOD (Table 2). Calves fed MOD and NTMOD consumed all of their MR offered, whereas calves fed HI consumed $97 \%$ of their MR offered throughout the nursery phase. Milk replacer DMI/calf averaged $27.4 \mathrm{~kg}$ for MOD and NTMOD and $40.3 \mathrm{~kg}$ for HI. Preweaning starter intake was less for calves fed HI versus $\operatorname{MOD}(P=0.01)$. Preweaning calf ADG tended to be greater $(P=0.06)$ and BCS change was greater $(P<0.01)$ for calves fed HI versus MOD. Preweaning medical treatment days (antibiotic treatment based on lethargy and high rectal temperatures) were fewer for calves fed NTMOD versus MOD $(P=0.01)$, but abnormal fecal days and fecal scores were similar among treatments. Postweaning (d 42 to 56), starter intake was less for calves fed HI versus MOD $(P=0.01)$ and tended to be less for calves fed NTMOD versus MOD $(P=0.07)$. Postweaning ADG was less for calves fed NTMOD versus MOD, but similar between MOD and HI. Hip width change tended to be less for HI versus MOD. Over the 56-d nursery trial, calves fed HI had less starter intake than calves fed MOD and calves fed NTMOD had fewer medical days than calves fed MOD.

During the grower phase, initial BCS score was greater $(P=0.05)$ but BCS change tended to be less for calves fed HI versus MOD $(P=0.08$; Table 3$)$. Hip width change was greater for calves fed MOD versus calves fed NTMOD and HI $(P<0.01)$. Final BW, ADG, DMI, and feed efficiency were similar among treatments in the grower phase.

Over the nursery and grower phases (d 0 to 112), total DMI were $233 \mathrm{~kg}$ for MOD, $241 \mathrm{~kg}$ for NTMOD, and $223 \mathrm{~kg}$ for HI. Total BW gain was $100 \mathrm{~kg}$ for MOD, $98 \mathrm{~kg}$ of NTMOD, and $102 \mathrm{~kg}$ for HI. Overall feed efficiency (BW gain/total DMI) was 0.384 for MOD, 0.366 for NTMOD, and 0.387 for HI. Total hip width change was $10.2 \mathrm{~cm}$ for MOD, $9.0 \mathrm{~cm}$ for NTMOD, and $9.2 \mathrm{~cm}$ for HI. Total BCS change was 0.8 units for all treatments. These data were not evaluated statistically because the experimental units differed between the nursery ( 1 calf) and grower (pen of 4 calves) trials.

\section{Apparent Diet Digestibility Estimates}

Digestibility was evaluated 5 to $10 \mathrm{~d}$ after weaning in the nursery trial (d 47 to 51; Table 4). Apparent digestibility of DM (74.4 vs. $71.3 \% ; P=0.01$ ), $\mathrm{OM}$ (76.2 vs. $72.8 \% ; P=0.005), \mathrm{ADF}(20.6$ vs. $8.2 \% ; P=$ 0.004 ), and NDF (27.9 vs. $16.9 ; P=0.01$ ) was greater for calves fed MOD versus NTMOD. Also, the apparent digestibility of DM (74.4 vs. $70.8 \% ; P=0.006), \mathrm{OM}$ (76.2 vs. $73.1 \% ; P=0.008), \mathrm{ADF}(20.6$ vs. $8.9 \% ; P=$ $0.006), \mathrm{NDF}(27.9$ vs. $17.8 ; P=0.02)$, and fat $(81.4$ vs. $74.3 \% ; P=0.01)$ was greater, and that of $\mathrm{CP}(68.5$ vs. $62.6 \% ; P=0.10)$ tended to be greater for calves fed MOD versus HI. Starch digestibility was similar regardless of preweaning treatments.

\section{DISCUSSION}

\section{Effects of Feeding Rate on Performance and Digestibility}

Growth and digestibility estimates observed in this study were similar to results previously reported by our group (Hill et al., 2013, 2016a,b) and Bach et al. (2013a) when calves were fed moderate and high rates of MR and observed until at least 4 mo of age. Reduced digestibility in the early postweaning period was also similar to other reports where digestion was estimated and was a contributing factor to reduced growth postweaning (Terré et al., 2007a; Hill et al., 2010, 2016a,b). In Hill et al. (2010), 2 trials estimated digestibility at d 53 to 56 . In the first trial, MR was fed at similar rates and calves were weaned at similar ages as the current study. In the second trial, MR was fed at similar rates but programs differed in weaning ages compared with the current study. Both trials illustrated OM digestibility was 4 to 5 percentage points lower when calves were fed up to $1.09 \mathrm{~kg}$ of DM from MR compared with calves fed $0.66 \mathrm{~kg}$ of DM from MR (Hill et al., 2010). More recently, Dennis et al. (2018) estimated digestibility at d 45 to 49 and d 56 to 60 when calves were fed 0.66 $\mathrm{kg} / \mathrm{d}$ or up to $1.09 \mathrm{~kg} / \mathrm{d}$ of MR DM and found no differences in OM digestibility. However, NDF digestibility was less when $1.09 \mathrm{~kg} / \mathrm{d}$ compared with $0.66 \mathrm{~kg}$ of MR $\mathrm{DM} / \mathrm{d}$ was fed to calves (Dennis et al., 2018). Quigley et al. (2018a) estimated digestibility at d 51 to 56 when calves were fed up to $1.07 \mathrm{~kg} / \mathrm{d}$ of MR DM and found reduced digestibility of OM, NDF, and ADF (regardless of starter composition) compared with feeding 0.66 $\mathrm{kg} / \mathrm{d}$ of MR DM. Quigley et al. (2018a) also reported that starch and NDF digestibility was influenced by 
Table 2. Performance of calves fed milk replacers at moderate rates with (NTMOD) and without (MOD) neomycin-oxytetracycline and at a high rate (HI) in the nursery trial

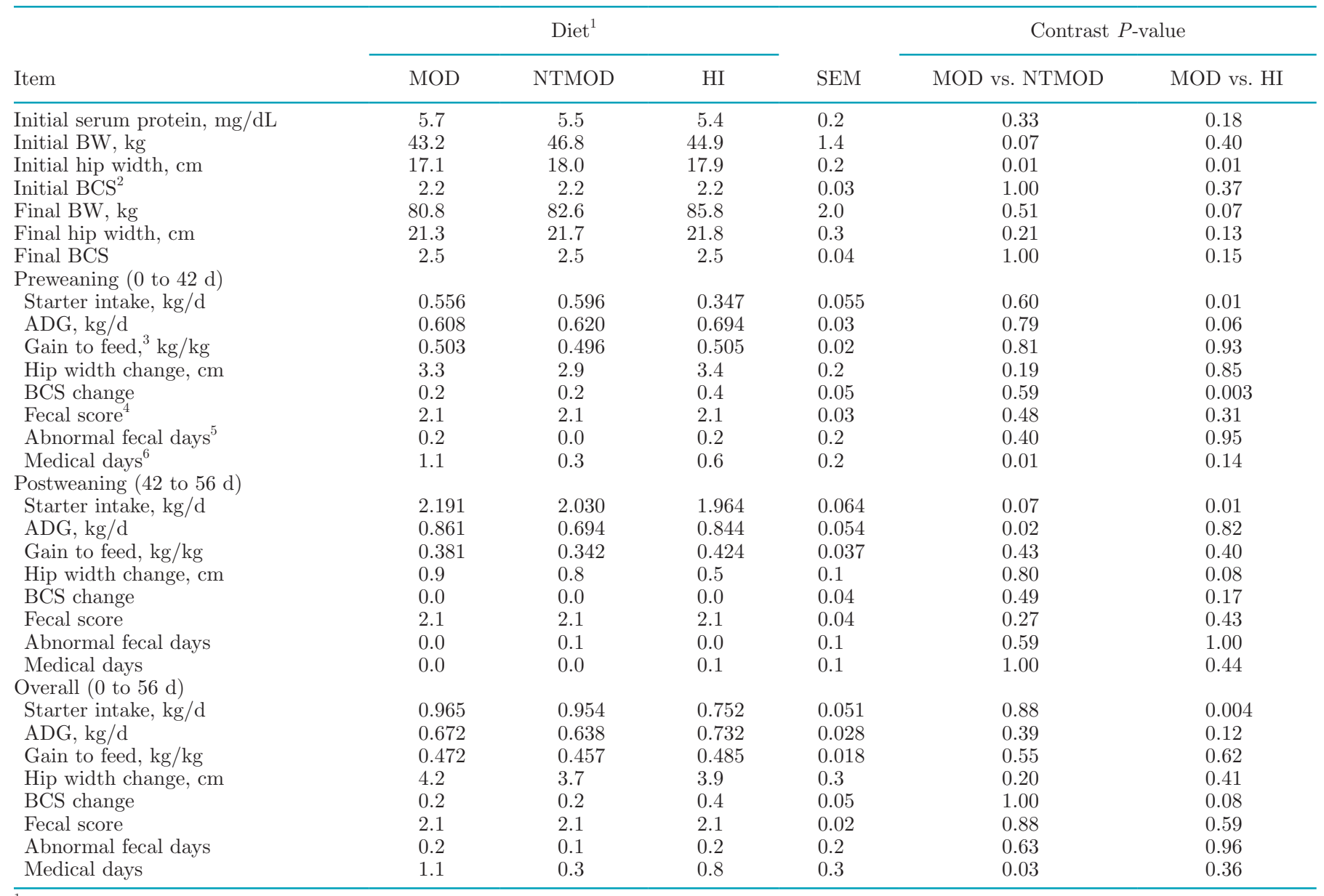

${ }^{1} \mathrm{MOD}$ and $\mathrm{NTMOD}=0.66 \mathrm{~kg}$ daily for $39 \mathrm{~d}$, then $0.33 \mathrm{~kg}$ daily for $3 \mathrm{~d}$; $\mathrm{HI}=0.85 \mathrm{~kg}$ daily for $4 \mathrm{~d}$, then $1.07 \mathrm{~kg}$ daily for $31 \mathrm{~d}$, then $0.53 \mathrm{~kg}$ daily for $7 \mathrm{~d}$ (DM basis).

${ }^{2} 1$ to 5 point system, with 1 being thin and 5 being obese.

${ }^{3} \mathrm{BW}$ gain divided by milk replacer plus starter intake.

${ }^{4} 1$ to 5 point system, with $1=$ thick; $2=$ less thick; $3=$ abnormal, like batter; $4=$ abnormal, watery with color; $5=$ abnormal, watery with little color.

${ }^{5}$ Days with fecal scores $>2$.

${ }^{6}$ Days with antibiotic treatments for fever and lethargy, not including electrolytes.

cumulative intake of NFC and NDF. Therefore, factors that delay starter intake can reduce the calf's ability to digest solid feed before milk or MR is withdrawn from the diet. Observable reductions in growth rate often occur when calves are fed large amounts of milk or milk replacer and, presumably, cannot obtain enough ME from starter once MR is removed (Miller-Cushon et al., 2013; Steele et al., 2017). More information on how accumulation of nutrient intake from dry feed (particularly NFC) influences digestive development and energy available from calf starters has been reported elsewhere (Quigley et al., 2018b). We are not aware of other studies that have evaluated the effects of MR feeding rate on diet digestibility around weaning.
Feed efficiency was not different between treatments from 0 to $56 \mathrm{~d}$. These findings are not surprising because preweaning feed efficiency responses to milk or MR feeding rate are mixed, often with no improvement observed (Hill et al., 2016a,b; Rosenberger et al., 2017). In contrast to our findings, Brown et al. (2005) reported feed efficiency improved with increasing MR feeding rates. Brown et al. (2005) fed either a standard plane of nutrition (1.1\% of BW of a $21 \% \mathrm{CP}, 21 \%$ fat MR with a $20 \% \mathrm{CP}$ starter) or a high plane of nutrition (2.0\% of BW of a $30 \%$ CP, $16 \%$ fat MR with a $25 \%$ $\mathrm{CP}$ starter) and weaned calves at 7 wk of age. Feeding a higher plane of nutrition increased feed efficiency approximately $25 \%$ from birth to 8 wk of age; however, 
Table 3. Performance of calves fed milk replacers at moderate rates with (NTMOD) and without (MOD) neomycin-oxytetracycline and at a high rate (HI) in the grower trial

\begin{tabular}{|c|c|c|c|c|c|c|}
\hline \multirow[b]{2}{*}{ Item } & \multicolumn{3}{|c|}{$\operatorname{Diet}^{1}$} & \multirow[b]{2}{*}{ SEM } & \multicolumn{2}{|c|}{ Contrast $P$-value } \\
\hline & MOD & NTMOD & HI & & MOD vs. NTMOD & MOD vs. HI \\
\hline Initial hip width, $\mathrm{cm}$ & 21.3 & 21.7 & 21.7 & 0.2 & 0.21 & 0.17 \\
\hline Initial BCS ${ }^{2}$ & 2.4 & 2.5 & 2.5 & 0.0 & 0.69 & 0.05 \\
\hline Final BW, kg & 143.7 & 145.0 & 146.2 & 3.2 & 0.78 & 0.60 \\
\hline Final hip width, cm & 27.3 & 27.0 & 27.1 & 0.2 & 0.39 & 0.52 \\
\hline $\mathrm{ADG}, \mathrm{kg} / \mathrm{d}$ & 1.12 & 1.12 & 1.08 & 0.05 & 0.99 & 0.63 \\
\hline Gain:feed ${ }^{3} \mathrm{~kg} / \mathrm{kg}$ & 0.353 & 0.339 & 0.340 & 0.010 & 0.37 & 0.40 \\
\hline Hip width change, $\mathrm{cm}$ & 6.0 & 5.3 & 5.3 & 0.1 & 0.006 & 0.008 \\
\hline BCS change & 0.5 & 0.5 & 0.4 & 0.1 & 1.00 & 0.08 \\
\hline
\end{tabular}

${ }^{1} \mathrm{MOD}$ and $\mathrm{NTMOD}=0.66 \mathrm{~kg}$ daily for $46 \mathrm{~d}$, then $0.33 \mathrm{~kg}$ daily for $3 \mathrm{~d}$; $\mathrm{HI}=0.85 \mathrm{~kg}$ daily for $5 \mathrm{~d}$, then $1.07 \mathrm{~kg}$ daily for $37 \mathrm{~d}$, then $0.53 \mathrm{~kg}$ daily for $7 \mathrm{~d}$ (DM basis).

${ }^{2} 1$ to 5 point system, with 1 being thin and 5 being obese.

${ }^{3} \mathrm{BW}$ gain divided by starter plus hay intake.

values reported in their study were similar to those observed in the current study. Bartlett et al. (2006) also reported feed efficiency increased for calves fed MR at $1.75 \%$ of $\mathrm{BW}$ compared with $1.25 \%$ of $\mathrm{BW}$, but calf starter was not offered and calves were not weaned in their study. As MR is considerably more digestible than calf starter, as evident in Dennis et al. (2018) when digestibility was estimated at $35 \mathrm{~d}$ of age, feed efficiency preweaning should improve with greater MR feeding rates. Bach et al. (2013b) reported insulin insensitivity caused by feeding large amounts of MR may partially explain lack of differences in feed efficiency compared with feeding less MR. However, we did not measure blood metabolites and cannot speculate if insulin insensitivity contributed to our observations.

In this study, BW and hip width change from 0 to $112 \mathrm{~d}$ did not appear to differ due to MR feeding rate (MOD vs. HI). This was also evident when MR were fed at the same maximum rates in 2 different studies by Dennis et al. (2017, 2018). Similarly, Hill et al. (2016b) reported similar 112-d BW and hip width gains when MR were fed at $0.66 \mathrm{~kg} / \mathrm{d}$ and weaning occurred at 42 d compared with feeding up to $1.1 \mathrm{~kg} / \mathrm{d}$ and weaning at $49 \mathrm{~d}$. When Hill et al. (2016a) fed calves up to 1.31 $\mathrm{kg} / \mathrm{d}$ and weaned at $49 \mathrm{~d}, 112-\mathrm{d}$ BW gain appeared to be slightly greater for calves fed $1.31 \mathrm{~kg} / \mathrm{d}$ versus calves fed $0.66 \mathrm{~kg} / \mathrm{d}$ and weaned at $49 \mathrm{~d}$, but 112-d hip width gain appeared slightly less for calves fed $1.31 \mathrm{~kg} / \mathrm{d}$.

\section{Effects of Antibiotics in Milk Replacer on Performance and Digestibility}

In this study, no calves were treated for respiratory sickness or had signs of nasal discharges or labored breathing. Sicknesses were observed in the first $43 \mathrm{~d}$ of the study and lethargy, fever, and diarrhea were likely

Table 4. Digestibility of nutrients by calves $(\mathrm{n}=5)$ fed milk replacers at moderate rates with (NTMOD) and without $($ MOD) neomycinoxytetracycline and at a high (HI) rate postweaning during d 47 to 51

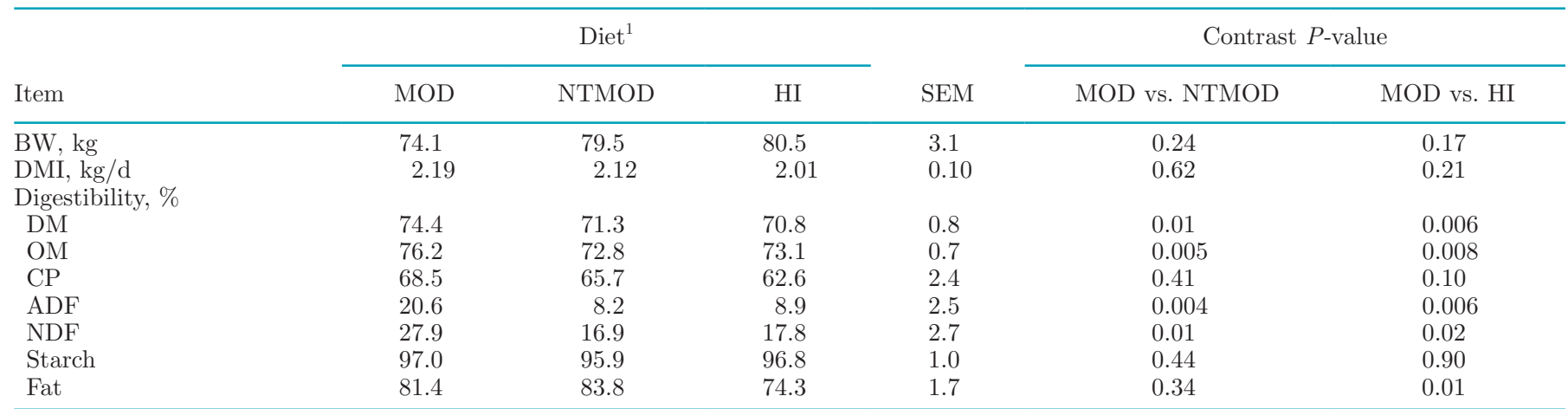

${ }^{1} \mathrm{MOD}=0.66 \mathrm{~kg}$ daily for $46 \mathrm{~d}$, then $0.33 \mathrm{~kg}$ daily for $3 \mathrm{~d}$; $\mathrm{HI}=0.85 \mathrm{~kg}$ daily for $5 \mathrm{~d}$, then $1.07 \mathrm{~kg}$ daily for $37 \mathrm{~d}$, then $0.53 \mathrm{~kg}$ daily for $7 \mathrm{~d}$ (DM basis). 
all indicative of digestive disease when detected. Overall, the calves were generally healthy. Antibiotics in the MR reduced medical days preweaning as expected, but the longer term effect on postweaning digestibility, postweaning ADG, and structural growth from d 56 to 112 was not expected. Reductions in digestibility due to extended antibiotic feeding has been previously observed in calves, as feeding chlortetracycline to milk-fed calves receiving dry feed reduced crude fiber digestibility at 9 (chopped alfalfa hay) and 13 wk (ground oats) of age (Bartley et al., 1956). However, Zinn (1993) reported only slight reductions in total-tract $\mathrm{OM}$ and starch digestibility in $164 \mathrm{~kg}$ Holstein steers fed diets with $71 \%$ concentrate and supplemented with chlortetracycline (350 mg/steer per day). Direct observations of reduced diet digestibility to feeding neomycin or oxytetracycline have not been reported in the literature, but some in vitro culture data have shown mixed results on cellulose digestibility. Fulghum et al. (1968) showed major cellulolytic species of rumen bacteria were susceptible to oxytetracycline, but not neomycin. Baldwin et al. (1982) reported chlortetracycline, oxytetracycline, and penicillin at $2.5 \mu \mathrm{g} / \mathrm{mL}$ concentrations inhibited in vitro cellulose degradation in mixed rumen cultures. In pure bacterial cultures, neomycin and oxytetracycline were shown to reduce specific growth rates of some fiber-digesting bacteria (Beharka and Nagaraja, 1998). Although in vitro data may not translate directly to in vivo feeding trials, substantial reductions in NDF and ADF digestibility observed for NTMOD immediately postweaning with no difference in starter intake suggest some inhibitory effects of antibiotics on fiber-digesting bacterial populations throughout the gastrointestinal tract. Therefore, negative effects may exist with continual antibiotic feeding, particularly during establishment of the rumen microbiome in pre-weaned calves.

In this study, antibiotics were fed for 40 of $42 \mathrm{~d}$ and between the duration and amount may have reduced rumen microbial populations and development. Presumably, milk or MR would be shunted to the abomasum due to esophageal groove closure. However, some calves may experience incomplete esophageal groove closure resulting in milk or MR flowing into the rumen. Using ultrasonography, Labussière et al. (2014) estimated about $20 \%$ of a MR meal (range of 0 to $39 \%$ ) can flow to the rumen in bucket-fed heavy veal calves not receiving solid feed. Berends et al. (2015) reported MR flowing to the rumen of nipple-fed veal calves given solid feed (measured using cobalt recovery) averaged about $20 \%$ of a meal. However, other researchers have reported even with meal sizes as large as $6.8 \mathrm{~L}$, nipple-fed calves offered whole milk did not experience any liquid feed entering the rumen (Ellingsen et al.,
2016). Despite conflicting evidence, it is reasonable to assume that some calves may experience liquid feed entering the rumen and therefore have exposure of the rumen microbiome to orally administered antibiotics on a regular basis. Exposure to antibiotics is a growing concern due to antibiotic-resistant genes manifesting in pathogenic bacteria, but may also be an issue when the rumen microbiome is developing in a young calf. Metagenomic analysis of rumen contents of calves fed waste or saleable milk has shown the phylum Bacteroidetes was the most susceptible to milk containing antibiotic residues (pasteurized or unpasteurized waste milk; Li et al., 2017). This is important as more than $50 \%$ of the relative abundance of bacterial phyla in the developing calf rumen microbiome comes from Bacteroidetes (Rey et al., 2014). Many of the bacterial species under Bacteroidetes are major utilizers of complex carbohydrates and potentially cellulose (Naas et al., 2014), making them indispensable when calves are first consuming solid feed.

\section{CONCLUSIONS}

Feeding up to $1.07 \mathrm{~kg}$ of MR or feeding neomycin with oxytetracyline with $0.66 \mathrm{~kg}$ of MR did not increase growth to 4 mo of age compared with feeding $0.66 \mathrm{~kg}$ of $\mathrm{MR} / \mathrm{d}$ without antibiotics using a $25 \% \mathrm{CP}, 17 \%$ fat MR. Although extra MR may have offered more preweaning growth, it did not improve calf health and reduced nutrient digestibility and structural growth postweaning. Feeding neomycin with oxytetracyline reduced medical days during the preweaning period, but reduced postweaning diet digestibility and structural growth. The current growth and digestibility measurements for these moderate and high MR feeding rate treatments were in agreement with numerous other measurements in the literature.

\section{ACKNOWLEDGMENTS}

The authors thank the staff at the Provimi Nurture Research Center for daily care and husbandry of calves used in these trials. This research was fully funded by Provimi, a division of Cargill Animal Nutrition.

\section{REFERENCES}

AOAC International. 2000. Official Methods of Analysis. Vol. I. 17th ed. AOAC International, Arlington, VA.

Bach, A., L. Domingo, C. Montoro, and M. Terré. 2013b. Short communication: Insulin responsiveness is affected by the level of milk replacer offered to young calves. J. Dairy Sci. 96:4634-4637.

Bach, A., M. Terré, and A. Pinto. 2013a. Performance and health responses of dairy calves offered different milk replacer allowances. J. Dairy Sci. 96:7790-7797. 
Baldwin, K. A., J. Bitman, and M. J. Thompson. 1982. Comparison of $\mathrm{N}, \mathrm{N}$-dimethyldodecanamine with antibiotics on in vitro cellulose digestion and volatile fatty acid production by ruminal microorganisms. J. Anim. Sci. 55:673-679.

Ballou, M. A. 2012. Immune responses of Holstein and Jersey calves during the preweaning and immediate postweaned periods when fed varying planes of milk replacer. J. Dairy Sci. 95:7319-7330.

Ballou, M. A., D. L. Hanson, C. J. Cobb, B. S. Obeidat, M. D. Sellers, A. R. Pepper-Yowell, J. A. Carrol, T. J. Earleywine, and S. D. Lawhon. 2015. Plane of nutrition influences the performance, innate leukocyte responses, and resistance to an oral Salmonella enterica serotype Typhimurium challenge in Jersey calves. J. Dairy Sci. 98:1972-1982.

Bartlett, K. S., F. K. McKeith, M. J. VandeHaar, G. E. Dahl, and J. K. Drackley. 2006. Growth and body composition of dairy calves fed milk replacers containing different amounts of protein at two feeding rates. J. Anim. Sci. 84:1454-1467.

Bartley, E. E., D. B. Parrish, and K. L. Wheatcroft. 1956. Antibiotics in dairy cattle nutrition. VI. The effects of Aureomycin feeding on the apparent digestibility of certain calf rations. J. Dairy Sci. 39:319-325.

Beharka, A. A., and T. G. Nagaraja. 1998. Effect of Aspergillus oryzae extract alone or in combination with antimicrobial compounds on ruminal bacteria. J. Dairy Sci. 81:1591-1598.

Berends, H., J. J. G. C. van den Borne, N. Stockhofe-Zurwieden, M. S. Gilbert, T. Zandstra, W. F. Pellikaan, C. G. van Reenen, E. A. M. Bokkers, and W. J. J. Gerrits. 2015. Effects of solid feed level and roughage-to-concentrate ratio on ruminal drinking and passage kinetics of milk replacer, concentrates, and roughage in veal calves. J. Dairy Sci. 98:5621-5629.

Berge, A. C. B., D. A. Moore, T. E. Besser, and W. M. Sischo. 2009. Targeting therapy to minimize antimicrobial use in preweaned calves: Effects on health, growth, and treatment costs. J. Dairy Sci. 92:4707-4714.

Berge, A. C. B., D. A. Moore, and W. M. Sischo. 2006. Field trial evaluating the influence of prophylactic and therapeutic antimicrobial administration on antimicrobial resistance of fecal Escherichia coli in dairy calves. Appl. Environ. Microbiol. 72:3872-3878.

Brown, E. G., M. J. VandeHaar, K. M. Daniels, J. S. Liesman, L. T. Chapin, D. H. Keisler, and M. S. Weber Nielsen. 2005. Effect of increasing energy and protein intake on body growth and carcass composition of heifer calves. J. Dairy Sci. 88:585-594.

Chester-Jones, H., B. J. Heins, D. Ziegler, D. Schimek, S. Schuling, B Ziegler, M. B. de Ondarza, C. J. Sniffen, and N. Broadwater. 2017. Relationships between early-life growth, intake, and birth season with first-lactation performance of Holstein dairy cows. J. Dairy Sci. 100:3697-3704.

Dennis, T. S., F. X. Suarez-Mena, T. M. Hill, J. D. Quigley, and R. L. Schlotterbeck. 2017. Effects of egg yolk inclusion, milk replacer feeding rate, and low-starch (pelleted) or high-starch (texturized) starter on Holstein calf performance through 4 months of age. J. Dairy Sci. 100:8995-9006.

Dennis, T. S., F. X. Suarez-Mena, T. M. Hill, J. D. Quigley, R. L. Schlotterbeck, and L. Hulbert. 2018. Effect of milk replacer feeding rate, age at weaning, and method of reducing milk replacer to weaning on digestion, performance, rumination, and activity in dairy calves to 4 months of age. J. Dairy Sci. 101:268-278.

Diaz, M. C., M. E. Van Amburgh, J. M. Smith, J. M. Kelsey, and E. L. Hutten. 2001. Composition of growth of Holstein calves fed milk replacer from birth to 105-kilogram body weight. J. Dairy Sci. 84:830-842.

Dubois, M., K. A. Gilles, J. K. Hamilton, P. A. Rebers, and F. Smith. 1956. Colorimetric method for determination of sugars and related substances. Anal. Chem. 28:350-356.

Eckert, E., H. E. Brown, K. E. Leslie, T. J. DeVries, and M. A. Steele. 2015. Weaning age affects growth, feed intake, gastrointestinal development, and behavior in Holstein calves fed an elevated plane of nutrition during the preweaning stage. J. Dairy Sci. 98:6315-6326.

Ellingsen, K., C. M. Mejdell, N. Ottesen, S. Larsen, and A. M. Grøndahl. 2016. The effect of large milk meals on digestive physiology and behaviour in dairy calves. Physiol. Behav. 154:169-174.
FASS. 2010. Guide for the Care and Use of Agricultural Animals in Agricultural Research and Teaching. 3rd ed. FASS Inc., Champaign, IL.

Fulghum, R. S., B. B. Baldwin, and P. P. Williams. 1968. Antibiotic susceptibility of anaerobic ruminal bacteria. Appl. Microbiol. $16: 301-307$.

Gelsinger, S. L., A. J. Heinrichs, and C. M. Jones. 2016. A metaanalysis of the effects of preweaned calf nutrition and growth on first-lactation performance. J. Dairy Sci. 99:6206-6214.

Griebel, P. J., M. Schoonderwoerd, and L. A. Babiuk. 1987. Ontogeny of the immune response: Effect of protein energy malnutrition in neonatal calves. Can. J. Vet. Res. 51:428-435.

Hall, M. B. 2009. Analysis of starch, including maltooligosaccharides, in animal feeds: A comparison of methods and a method recommended for AOAC collaborative study. J. AOAC Int. 92:42-49.

Hengst, B. A., L. M. Nemec, R. R. Rastani, and T. F. Gressley. 2012. Effect of conventional and intensified milk replacer feeding programs on performance, vaccination response, and neutrophil mRNA levels of Holstein calves. J. Dairy Sci. 95:5182-5193.

Hill, T. M., J. M. Aldrich, R. L. Schlotterbeck, and H. G. Bateman II. 2007. Effects of the feeding rate of high protein calf milk replacers. Prof. Anim. Sci. 23:649-655.

Hill, T. M., H. G. Bateman II, J. M. Aldrich, J. M. Quigley, and R. L. Schlotterbeck. 2013. Evaluation of acidified, ad libitum milk replacer programs for dairy calves. J. Dairy Sci. 96:3153-3162.

Hill, T. M., H. G. Bateman II, J. M. Aldrich, and R. L. Schlotterbeck. 2010. Effect of milk replacer program on digestion of nutrients in dairy calves. J. Dairy Sci. 93:1105-1115.

Hill, T. M., H. G. Bateman II, J. M. Aldrich, R. L. Schlotterbeck, and K. G. Tanan. 2008. Optimal concentrations of lysine, methionine, and threonine in milk replacers for calves less than five weeks of age. J. Dairy Sci. 91:2433-2442.

Hill, T. M., J. D. Quigley, H. G. Bateman II, J. M. Aldrich, and R. L. Schlotterbeck. 2016a. Effect of milk replacer feeding rate and functional fatty acids on dairy calf performance and digestion of nutrients J. Dairy Sci. J. Dairy Sci. 99:6352-6361.

Hill, T. M., J. D. Quigley, H. G. Bateman II, F. X. Suarez-Mena, T. S. Dennis, and R. L. Schlotterbeck. 2016b. Effect of milk replacer program on calf performance and digestion of nutrients in dairy calves to 4 months of age. J. Dairy Sci. 99:8103-8110.

Hill, T. M., M. J. VandeHaar, L. M. Sordillo, D. R. Catherman, H. G. Bateman II, and R. L. Schlotterbeck. 2011. Fatty acid intake alters growth and immunity of milk-fed calves. J. Dairy Sci. 94:39363948.

Kertz, A. F., and H. Chester-Jones. 2004. Invited Review: Guidelines for measuring and reporting calf and heifer experimental data. J. Dairy Sci. 87:3577-3580.

Labussière, E., H. Berends, M. S. Gilbert, J. J. G. C. van den Borne, and W. J. J. Gerrits. 2014. Estimation of milk leakage into the rumen of milk-fed calves through and indirect and repeatable method. Animal 8:1643-1652.

Li, W., W. Han, X. Yuan, G. Wang, Z. Wang, Q. Pan, Y. Gao, and Y. Qu. 2017. Metagenomic analysis reveals the influences of milk containing antibiotics on the rumen microbes of calves. Arch. Microbiol. 199:433-443.

Litherland, N. B., D. Carlson, D. Ziegler, B. Ziegler, D. Schimek, M. Raeth-Knight, G. Golombeski, H. Chester-Jones, and J. Linn. 2010. Growth and health of calves pre- and post-weaning fed milk replacers with differing levels of neomycin sulfate and oxytetracycline. J. Dairy Sci. 93(E-Suppl. 1):301. (Abstr.)

Littell, R. C., P. R. Henry, and C. B. Ammerman. 1998. Statistical analysis of repeated measures data using SAS procedures. J. Anim. Sci. 76:1216-1231.

Maynou, G., A. Bach, and M. Terré. 2017. Feeding waste milk to Holstein calves affects antimicrobial resistance of Escherichia coli and Pasteurella multocida isolated from fecal and nasal swabs. J. Dairy Sci. 100:2682-2694.

Meale, S. J., L. N. Leal, J. Martín-Tereso, and M. A. Steele. 2015. Delayed weaning of Holstein bull calves fed an elevated plane of nutrition impacts feed intake, growth and potential markers of gastrointestinal development. Anim. Feed Sci. Technol. 209:268-273. 
Miller-Cushon, E. K., R. Bergeron, K. E. Leslie, and T. J. DeVries. 2013. Effect of milk feeding level on development of feeding behavior in dairy calves. J. Dairy Sci. 96:551-564.

Naas, A. E., A. K. Mackenzie, J. Mravec, J. Schuckel, W. G. T. Willats, V. G. H. Eijsink, and P. B. Pope. 2014. Do rumen Bacteroidetes utilize an alternative mechanism for cellulose degradation? MBio 5:e01401-e01414.

Ollivett, T. L., D. V. Nydam, T. C. Linden, D. D. Bowman, and M. E. Van Amburgh. 2012. Effect of nutritional plane on health and performance in dairy calves after experimental infection with Cryptosporidium parvum. J. Am. Vet. Med. Assoc. 241:1514-1520.

Quigley, J. D., T. M. Hill, T. S. Dennis, F. X. Suarez-Mena, and R. L. Schlotterbeck. 2018a. Effects of feeding milk replacer at 2 rates with pelleted, low-starch or texturized, high-starch starters on calf performance and digestion. J. Dairy Sci. 101:5937-5948.

Quigley, J. D., T. M. Hill, J. R. Knapp, W. Hu, T. S. Dennis, F. X Suarez-Mena, and R. L. Schlotterbeck. 2018b. Prediction of metabolizable energy in calf starters. J. Dairy Sci. 101(Suppl. 2):264.

Quigley, J. D., T. A. Wolfe, and T. H. Elsasser. 2006. Effects of additional milk replacer feeding on calf health, growth, and selected blood metabolites in calves. J. Dairy Sci. 89:207-216.

Rey, M., F. Enjalbert, S. Combes, L. Cauquil, O. Bouchez, and V. Monteils. 2014. Establishment of ruminal bacteria community in dairy calves from birth to weaning is sequential. J. Appl. Microbiol. 116:245-257.

Robertson, J. B., and P. J. Van Soest. 1981. The Detergent System of Analysis and Its Application to Human Foods. Cornell University, Ithaca, NY.

Rosenberger, K., J. H. C. Costa, H. W. Neave, M. A. G. von Keyserlingk, and D. M. Weary. 2017. The effect of milk allowance on behavior and weight gains in dairy calves. J. Dairy Sci. 100:504-512.

Steele, M. A., J. H. Doelman, L. N. Neal, F. Soberon, M. Carson, and J. A. Metcalf. 2017. Abrupt weaning reduces postweaning growth and is associated with alterations in gastrointestinal markers of development in dairy calves fed an elevated plane of nutrition during the preweaning period. J. Dairy Sci. 100:5390-5399.
Terré, M., M. Devant, and A. Bach. 2007a. Effect of level of milk replacer fed to Holstein calves on performance during the preweaning period and starter digestibility at weaning. Livest. Sci. 110:82-88.

Terré, M., M. Devant, and A. Bach. 2007b. Performance and nitrogen metabolism of calves fed conventionally or following an enhancedgrowth feeding program during the preweaning period. Livest. Sci. 105:109-119.

Urie, N. J., J. E. Lombard, C. B. Shivley, C. A. Kopral, A. E. Adams, T. J. Earleywine, J. D. Olson, and F. B. Garry. 2018. Preweaned heifer management on US dairy operations: Part I. Descriptive characteristics of preweaned heifer raising practices. J. Dairy Sci. 101:9168-9184.

Van Keulen, J. V., and B. A. Young. 1977. Evaluation of acid insoluble ash as a natural marker in ruminant digestibility studies. J. Anim. Sci. 44:282-287.

Van Soest, P. J., J. B. Robertson, and B. A. Lewis. 1991. Methods for dietary fiber, neutral detergent fiber, non-starch polysaccharides in relation to animal nutrition. Symposium: Carbohydrate methodology, metabolism and nutritional implications in dairy cattle. J. Dairy Sci. 74:3583-3597.

von Keyserlingk, M. A. G., J. Rushen, A. M. de Passillé, and D. M. Weary. 2009. Invited Review: The welfare of dairy cattle-Key concepts and the role of science. J. Dairy Sci. 92:4101-4111.

Walker, W. L., W. B. Epperson, T. E. Wittum, L. K. Lord, P. J Rajala-Schultz, and J. Lakritz. 2012. Characteristics of dairy calf ranches: Morbidity, mortality, antibiotic use practices, and biosecurity and biocontainment practices. J. Dairy Sci. 95:2204-2214.

Wildman, E. E., G. M. Jones, P. E. Wagner, R. L. Boman, H. F. Trout Jr., and T. N. Lesch. 1982. A dairy cow body condition scoring system and its relationship to selected production characteristics. J. Dairy Sci. 65:495-501.

Zinn, R. A. 1993. Influence of oral antibiotics on digestive function in Holstein steers fed a 71\% concentrate diet. J. Anim. Sci. 71:213217. 